\title{
On Medieval Storytelling. The Story of Melchizedek in Certain Slavonic Texts (Palaea Historica and the Apocryphal Cycle of Abraham)
}

In medieval Slavonic literature thematically related to the Book of Genesis, Melchizedek occupies a particularly important place, having been an object of interest for many commentators for the past one hundred and fifty years. It is at least partly due to the fact that while interest in Melchizedek in the traditional patristic corpus is rather one-sided, in the Christian Oriental traditions and Byzantine literature there are entirely new concepts, mostly of a legendary nature, incorporating the venerable king-priest in the history of salvation, told in simple language, using popular didactic motifs and figures ${ }^{1}$. Oleg Tvorogov emphasises that it was the limited number of biblical sources concerning Melchizedek that became the incentive for the emergence of legends about that figure, as early as the Byzantine era ${ }^{2}$.

The most important catalogues classifying early Christian literary heritage devoted to the figure of Melchizedek include: Clavis Apocryphorum Veteris Testamenti, where the entry De Sacerdotio Methusalem, Nir et Melchisedek contains a reference to the Slavonic Book of Enoch ${ }^{3}$, and Bibliotheca Hagiographica Graeca, the third volume of which (under the entry for Melchisedech rex Salem) lists four variants of the story of the king-priest, including the one by Athanasius of Alexandria and the 'Commentarius' in the context of Palaea Historica ${ }^{4}$. Bibliographies with almost two hundred entries - including studies on the figure of Melchizedek in the canonical texts (such as writings and commentaries of the Church Fathers) and non-canon sources representing different languages and cultures, as well as an index of studies and commentaries devoted to him - can be found, for example, in

\footnotetext{
${ }^{1}$ R. ZarZeCZny, Melchizedek $w$ literaturze wczesnochrześcijańskiej i gnostyckiej, Katowice 2009 [= SAC, 9], p. 25.

${ }^{2}$ О.В. Творогов, Апокрифы о Мельхиседеке, [in:] Словарь книжников и книжности Древней $P y c u$, t. I, XI - первая половина XIV в., ed. Д.С. ЛихАчев, Ленинград 1987, p. 62-63.

${ }^{3}$ De sacerdotio Methusalem, Nir et Melchisedek, p. 51 [V. Henoch Slauicum, LXVIII, versio rumaena (e slavico): M. Gaster, Chrestomathie roumaine I, p. 65-68, cod. BAN 469, XVII sec.], [in:] Clavis Apocryphorum Veteris Testamenti, cura et studio J.-C. HAELEWYCK, Brepols-Turnhout 1998, no. 78. ${ }^{4}$ Melchisedech rex Salem (2268, 2268b, 2269, 2269b, 2269c), [in:] Bibliotheca Hagiographica Graeca, vol. III, ed. F. Halkin, Bruxelles 1957, p. 48-49.
} 
the monographs by Rafał Zarzeczny ${ }^{5}$ and Igor Tantlevskij, thus proving the singular importance of the king of Salem for theology, dogmatics and art of the early centuries of Christianity. Christfried Böttrich wrote a study based on the genological and chronological criterion that is crucial to the history of representations of Melchizedek in the Slavonic tradition ${ }^{7}$. It is an overview of various types of the story of Melchizedek taking into account the historical and commented Palaea, the prologue and the Menaion, homiletic works, chronographs, codices (sborniki), as well as the interpretation of the figure in apocalyptic and ascetic works.

The stories of Melchizedek from Slavonic historical texts representing various genres, typically collectively referred to as "apocrypha", were published as early as in the late nineteenth century by Alexander Pypin ${ }^{8}$, Nikolaj Tikhonravov ${ }^{9}$, Ivan Porfiriev $^{10}$, Ivan Franko ${ }^{11}$, and even those pioneering publishers already suggested a classification. And so Porphiriev distinguished essentially three types of texts: those containing a description of the genealogy of Melchizedek, those emphasizing his unusual origins (as he supposedly did not know his parents), and the Sermon by Athanasius of Alexandria, used as a reading on the liturgical feast of Melchizedek on $22 \mathrm{May}^{12}$. Alexander Jacimirskij's catalogue, to a greater extent based on the genological characteristics of texts than Porphiriev's commentary, notes ${ }^{13}$ : firstly,

\footnotetext{
${ }^{5}$ Bibliography comprised of more than a hundred items (excluding edition of sources) in: $\mathrm{R}$. $\mathrm{ZA}$ RZECZNY, op. cit., p. 370-403.

${ }^{6}$ И.Р. ТАнтлЕвский, Мелхиседек и Метатрон в иудейской мистико-апокалиптической традииии, Санкт-Петербург 2007.

${ }^{7}$ Chr. BötTrich, Die „Geschichte Melchisedeks” (HistMelch) im slavischen Kulturkreis, [in:] The Old Testament Apocrypha in the Slavonic tradition: continuity and diversity, ed. L. DiTommaso, Chr. Bötтrich, coll. M. SwoвоdA, Tübingen 2011, p. 159-200. For the complete image of Melchizedek in Christian writings, cf. also in the monograph: CHr. BöTtrich, Geschichte Melchisedeks, München 2010 [= JSHZ.NF, 21]; reviewed in: А. МАштАкова, [in:] Свящзенное писание как фактор языкового и литературного развития. Материаль Международной конференции „Священное Писание как фактор языкового и литературного развития (в ареале авраамических религий), СанктПетербург, 30 июня 2009 г., еd. Е.Н. МЕщЕРСКАЯ, Санкт-Петербург 2011, р. 296-305.

${ }^{8}$ The list overlooks historical texts such as various types of palaeas or chronicles, edited as a whole, an element of which is the story of Melchizedek. Cf. three texts in: A.Н. Пыпин, Ложные и отреченные книги русской старины [Памятники старинной русской титературы, издаваемые Грабом Григорием Кушелевым-Безбородко], vol. III, Санкт-Петербург 1862, p. 20-23.

9 Two texts in: Н.С. Тихонравов, Памятники отреченной русской литературы, vol. I, СанктПетербург 1863, p. 26-31.

${ }^{10}$ Three texts in: И.Я. ПорфИРьев, Апокрифическия сказания о ветхозаветных тииах и событиях по рукописям Соловеикой библиотеки, СОРЯС 17.1, 1877, p. 131-135, 222-225, 256-259.

${ }_{11}^{11}$ Two texts in: Апокрифи і лезенди з українських рукописів, еd. I.Я. ФРАнКо, vol. I, Апокрифи старозавітні, Львів 2006, р. 92-101.

${ }^{12}$ И.Я. ПОРФИРЬЕВ, ор. cit., p. 53.

${ }^{13}$ А.И. ЯцимиРский, Мельхиседек, [in:] Библиографический обзор апокрифов в южнославянской и русской письменности (списки памятников), t. I, Апокрифы ветхозаветные, Петроград 1921, p. 100-111. Commentary to the part on Melchizedek: В индексах не упоминаемый, статьи о Мельхиседеке частью связаны в рукописях с историей Авраама, частью самостоятельны в них, как памятники, но в подборе 'апокрифических' статей по ветхозаветной истории в известнаго рода южнославянских сборниках (типа Тиквешскаго) всегда занимают определенное место. На русской почве оне были вытеснены Словом, приписываемым Абанасию, и проложной статей, ibidem, p. 100.
} 
On Melchizedek, close to the cycle of stories about the Old Testament heroes in South Slavonic copies from which they are derived ${ }^{14}$; secondly, the text of the Prologue on the liturgical feast of $22 \mathrm{May}^{15}$; thirdly, Sermon of Athanasius of Alexandria (read on that day); fourthly, a collection of works comprised of 14 units "whose origin and literary history has not been explained", contaminating themes present in the above-mentioned text ${ }^{16}$, and fifthly, unidentified/unspecified texts ${ }^{17}$.

In recent years, variants of the story of Melchizedek in manuscripts of Serbian origin have been discussed by Tomislav Jovanović in his edition of a fragment of the first translation of the Palaea from the so-called Gorica Codex ${ }^{18}$, while Alexandra Mashtakova published the text from the Chronograph ${ }^{19}$.

Rafał Zarzeczny, an expert on Melchizedek in the early Christian apocrypha, notes that Melchizedek disappears from the Bible pages just as suddenly as he first appeared, as in verses 21 and 22 [the biblical - MS] hagiographer returns to the previously mentioned Abraham's encounter with the king of Sodom, and their dialogue refers only to the return of the royal assets recovered by the patriarch during a war expedition ${ }^{20}$.

Extract of Gen 14,17-20 is the first and only Biblical account directly relating to Melchizedek. Almost all the remaining references to this figure in the Old and New Testament present Melchizedek as a model priest (Ps 110,4, Heb 5,6-10, Heb 6,20 ), and a more detailed information can be found in the Letter to the Hebrews (Heb 7,1-17).

The limited volume of biblical material concerning Melchizedek is easily confronted with his story recorded in Palaea Historica - a singular summary of the first books of the Old Testament, which has never been on any indices of restricted or prohibited books, but described by scholars of medieval Slavonic literature as

\footnotetext{
${ }^{14}$ Ibidem, p. 100.

${ }^{15}$ Мелхиседека праведнаго, ияаря Саломскаго, after: АрХиЕПИскоП СЕРГИй (СПАССКИй), Полныи месяцеслов Востока, vol. II Святый Восток, p. I, Москва 1997, p. 153 (ibidem, 3 March and 12 April as dates of liturgical feast in local calendars).

${ }_{16}^{16}$ А.И. ЯцимиРский, ор. сit., p. 109.

${ }^{17}$ А.И. ЯцимиРский, op. cit., p. 110-111.

${ }^{18}$ T. Јовановић, Апокриф о Мелхиседеку у преписи Горичког зборника, [in:] Никон Јерусалимаи. Вријеме - личности - дјело. Зборник радова са међународног научног симпосиона на Скадарском језеру 7.-9. септембра 2000. године, Цетиње 2004, p. 223-235. The story of Melchizedek from the Gorica Codex, published by Jovanović as an annex to the study, corresponds to the fragment on Melchizedek from the first translation of Palaea Historica.

${ }^{19}$ Слово от Ветхаго Закона о Мелхыседеци, [in:] А.Г. МАштАкова, К изучению апокрифа о Мелхиседеке в составе Полной Хронографической Палеи, ТОДЛ 61, 2010, p. 378-381 (the entire text on p. 375-381).

${ }^{20}$ R. ZARZECZNY, op. cit., p. 13.
} 
containing elements of non-canonical and apocryphal nature. The vast majority of the story (i.e. the history of Melchizedek in the Palaea) has a biblical origin. R. Zarzeczny refers, inter alia, to a text published in 1893 by A. Vassiliev, registered in the BHG catalogue under reference number 2269, called The Legend of Melchizedek and described as "a longer Greek version", is in fact a fragment of Palaea Historica (although in other texts, such as the Prologue for 22 May or Sermon of Athanasius and the Apocalypse of Pseudo-Methodius, the story is more varied) ${ }^{21}$. Moreover, the pages of Vassiliev's edition cited by Zarzeczny based in the BHG include - in

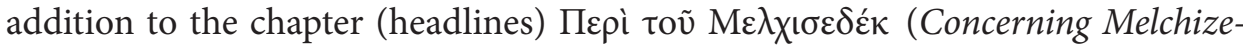

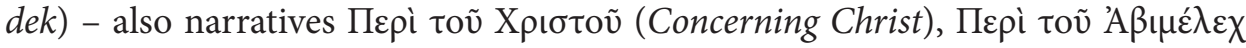

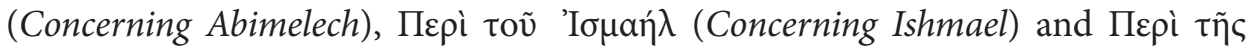
aix $\mu \alpha \lambda \omega \sigma i a \varsigma, \Lambda \omega \tau$ (Concerning the Captivity of Lot), in which Melchizedek is a secondary character ${ }^{22}$.

Cited here are excerpts from two Slavonic translations of the Palaea: the first one, in Andrei Popov's edition (hereinafter Palaea I), the second, based on the manuscript ref. 42 from the Library of the Museum of the Serbian Orthodox Church in Belgrade, ff. 56-112 (the so-called Krušedol Palaea, hereinafter Palaea II). They will be compared to the so-called apocryphal cycle of Abraham (available in two versions) ${ }^{23}$, where Melchizedek is one of the most important figures. The source of the first edition of the cycle is the fifteenth-century manuscript from the Monastery of St. Paul on Mount Athos edited by Petr Lavrov ${ }^{24}$ (hereinafter: cycle I); the source of the second one is the so-called Codex of Tikveš from the fifteenthcentury edited by Načo $\mathrm{Načov}^{25}$ (hereinafter: cycle II). The cycle (translated for the first time ca. $10^{\text {th }}$ or $11^{\text {th }}$ century) and Palaea Historica are the oldest (extra-biblical) Slavonic historical texts containing the story of Melchizedek, present in literature for several hundred years - in miscellanea, chronicles and collections of stories

\footnotetext{
${ }^{21}$ P. Piovanelli, The Story of Melchizedek with the Melchizedek Legend from the Chronicon Paschale, [in:] Old Testament Pseudepigrapha. More Noncanonical Scriptures, vol. I, p. 64 (the entire text on p. 64-84). Also the English translation of the sources commented therein (and completed with lessons based on the Ethiopian fragments edition) based on the editions: J.-P. Migne - Historia de Melchisedec, PG, vol. 28, 1857, p. 523-530 (The Story of Melchizedek); L.A. Dindorf - Chronicon Paschale, vol. I, Bonn 1832 (On Melchizedek from the Chronicon Paschale).

${ }^{22}$ Zarzeczny's study takes into account only the Greek and Oriental variants of the Legend of Melchizedek (Coptic, Armenian, Arab, Syrian, in the Ge'ez language). Titles of chapters after the English translation of the Palaea: W. Adler, Palaea Historica ("The Old Testament History"). A New Translation and Introduction, [in:] Old Testament Pseudepigrapha. More Noncanonical Scriptures, vol. I, ed. R. Bauckham, J.R. Davila, A. Panayotov, Michigan 2013, p. 585-672.

${ }^{23}$ Polish translation of extensive fragments of Legend of Melchizedek from Greek in: R. ZARZECZNY, op. cit., p. 335, 337, 346-349 (trans. IDEM); English translation in: P. PiovanELLI, op. cit., p. 77-84.

${ }^{24}$ Apocryphal cycle of Abraham in the so-called version I: Сказания об Аврааме [Влово правєднаго

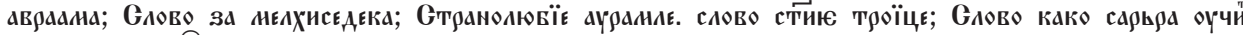

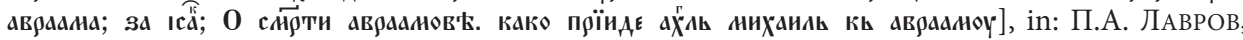
Апокрифические тексты, СОРЯС 67, 1899, p. 70-81.

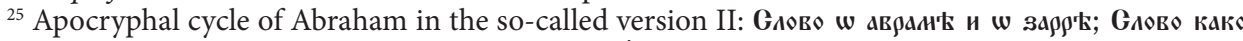

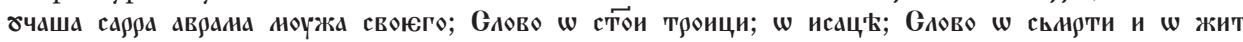
аврановв, in: Н.А. НАЧОв, Тиквешки рбкопис, СНУНК 8, 1892, p. 406-413.
} 
about the history of the world from its origins to the Middle Ages. In addition, the apocryphal nature of the cycle is uncontested ${ }^{26}$, and the use of non-canon elements in Palaea Historica has been the subject of discussion (especially in the works by Emile Turdeanu ${ }^{27}$ ). The chapter Concerning Melchizedek in Palaea Historica and Sermon on Melchizedek from the cycle (in the second edition of the cycle Sermon on How Sarah Instructed Her Husband Abraham) essentially address the same time and describe the same events in the life of Melchizedek and Abraham. It is doubtlessly a selection of events that are most interesting and important from the point of view of the plot and character development (at least on the Slavonic material).

Naturally, most of the versions of the figure of Melchizedek in Slavonic extrabiblical texts have their prototypes in Byzantine works, and it is in the context of the latter that they have been usually interpreted. For example, The Apocalypse of Pseudo-Methodius of Patara mentions that Melchizedek was supposedly born "from a dead mother" - Sophonim, who died shortly before giving birth ${ }^{28}$. This theme is probably inspired by The Slavonic Book of Enoch ${ }^{29}$ and found in fifteenthand sixteenth-century East Slavonic $\operatorname{copies}^{30}$. Noah was said to hide the newborn baby for 40 days (again, a symbolic number) in an underground cave, protecting the boy from villains who wanted him dead. Having listened to Noah's prayers, God sent an angel who took the child "to the earthly paradise" (or "the paradise of Eden", as we read in The Slavonic Book of Enoch ${ }^{31}$ ), from where Melchizedek - now an adult - came down to a hermitage on Mount Tabor, where he met Abraham. In The Apocalypse of Pseudo-Methodius Melchizedek is the son of a priest called Nir, identified as the second son of Lamech, and the brother of Noah (while the Hebrew tradition associates Melchizedek - also known as Adoni-Sedeq - with Shem, ancestor of Abraham, whom, as his successor, he is believed to have taught his priestly duties ${ }^{32}$ ). The genealogy of Melchizedek - found in different variants ${ }^{33}$

\footnotetext{
${ }^{26}$ Cf. e.g.: A. Miltenova, The Apocryphal Series about Abraham, [in:] Studia Caroliensia. Papers in Linguistics and Folklore in Honor of Charles E. Gribble, ed. R.A. Rothstein, E. Scatton, C.E. Townsend, Bloomington 2006, p. 189-208.

${ }^{27}$ E. Turdeanu, La Palaea Byzantine chez les slaves du Sud et chez les Roumains, RES 40, 1964, p. 195-206.

${ }_{28}$ Cf. М. Сковронэк, О списке „Апокалипсиса” Псевдо-Мефодия („Откровения Мефодия Патарскаго о последних временех") Государственного архива в Бухаресте, Pbg 35.3, 2011, p. 84-85 (the entire text on p. 74-115).

${ }^{29}$ И.Р. ТАНТЛЕВСКИЙ, ор. cit., p. 12.

${ }^{30}$ Cf. Р.Б. ТАРковский, Сказание о Мехиседеке [комментар], [in:] Апокрифы Древней Руси, coll. et introd. М.В. РОЖДЕСтвенСКАЯ, Санкт-Петербург 2006, p. 213-214.

${ }^{31}$ According to this book, Melchizedek is sheltered from the deluge "in the paradise of Eden" by Archangel Michael, cf. Ksiega Henocha słowiańska, trans. R. Rubinkiewicz, [in:] Apokryfy Starego Testamentu, ed. R. Rubinkiewicz, Warszawa 2000, p. 197-214. In the story of Nir's wife, archangel Gabriel takes care of Melchizedek, cf. Сказание о Мелхиседеке. О жене Нира, trans. Р.Б. ТАРКОВСКИЙ, [in:] Апокрифы Древней Руси..., p. 33-37.

${ }^{32}$ R. Graves, R. Patai, Mity hebrajskie. Ksiega Rodzaju, trans. R. Gromacka, Warszawa 1993, p. 153.

${ }^{33}$ On genealogies of Melchizedek in Syrian, Greek and Armenian writings cf. R. ZARzEczNY, op. cit., p. 335-356. On identification of Melchizedek with other heroes of the Old Testament, cf.
} 
- is in Palaea Historica reduced to the names of his father (Josedek or Osedek) and mother (Salim or Salima) and a mention that he was one of the "grandchildren of Nimrod".

It is estimated that, despite some fairly significant differences (mainly structural, but also for example the presence of folkloric elements in the later variant), two editions of the Abraham cycle preserved in Slavonic manuscripts are derived from the same Greek source ${ }^{34}$. Assuming that the theory of more than one Slavonic translation of Palaea Historica is true, can the two older ones (out of a total of three), written between the late $10^{\text {th }}$ and early $13^{\text {th }}$ century, be regarded as a single text? Certain parts, such as the anathemas against heretics present only in the second translation, suggest that the text was subject to revisions in the Byzantine period, which is reflected in the Slavonic translation ${ }^{35}$. In the episodes featuring Abraham and Melchizedek found in the first two translations there are virtually no fragments which are identical (in terms of style, which in a way implies minor differences in content $)^{36}$. The list of differences - lexical, grammatical and syntactic, stylistic, inversions, additions or omissions - is comprised of nearly one hundred items ${ }^{37}$. Such significant differences are rather the result of individual skills and the specific characteristics of the literary and cultural (as well as linguistic or dialectal)

A.A. OrLov, Melchizedek Legend of 2 (Slavonic) Enoch, JSJ 31, 2000, p. 23-38 [www.marquette.edu/ maqom/melchizedek.html, 20 VIII 2011]; IDEM, Noah's younger brother? The Anti-Noachic polemics in 2 Enoch, [in:] Henoch, vol. XXII, 2009, p. 207-221.

${ }^{34}$ D.C. Allison, Testament of Abraham, Berlin 2003, p. 27, cited after: A. Miltenova, The Apocryphal Series about Abraham...

${ }^{35}$ Cf. M. SKowronek, Remarks on the anathemas in the Palaea Historica, SCer 3, 2013, p. 131-144.

${ }^{36}$ These are the most similar phrases (from Palaea I and Palaea II respectively): $\chi^{\circ т \text { А }}$ исполнити

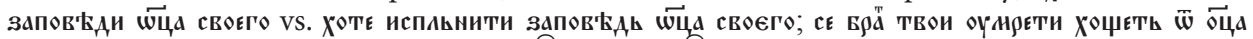

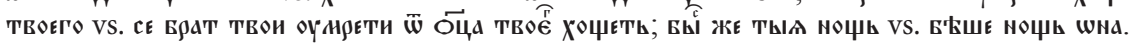

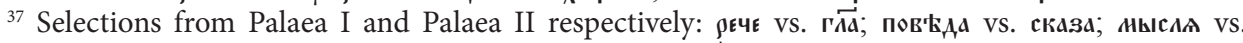

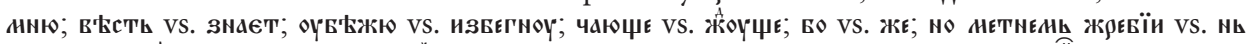

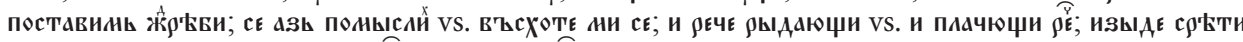

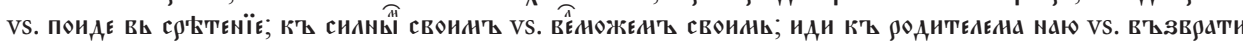

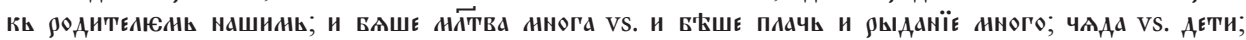

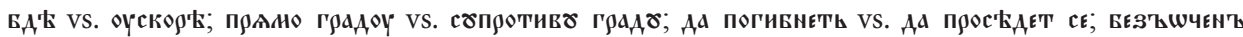

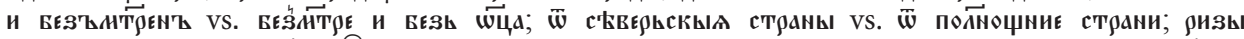

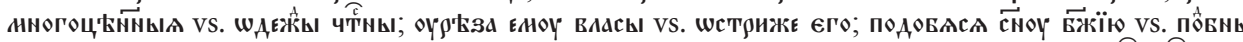

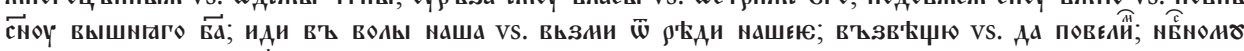

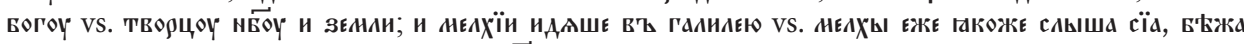

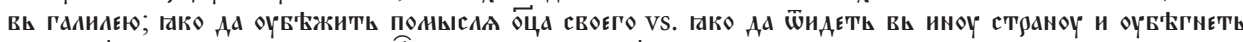

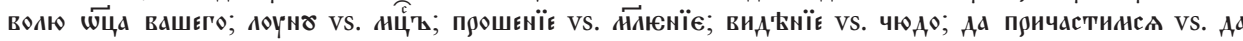

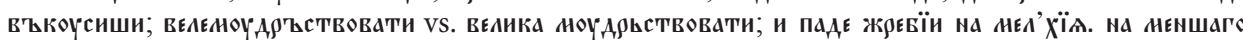

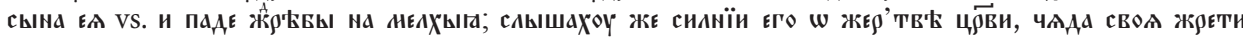

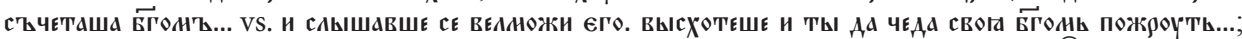

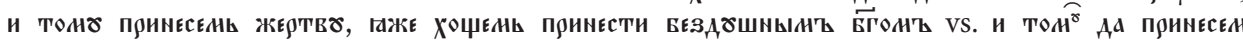

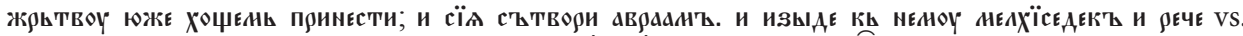

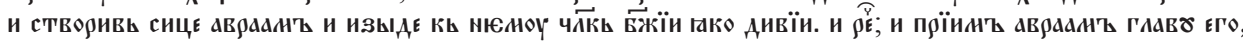

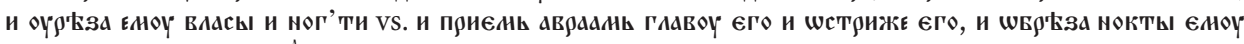

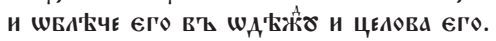


milieux of translators. These two translations of the Palaea are a singular example of syntactic synonymy as a way of diverse expression of specific content ${ }^{38}$.

In Palaea Historica, most of Melchizedek's life was presented in the chapter

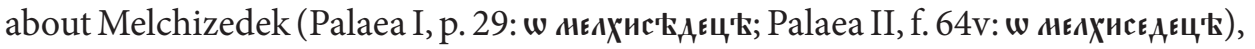
but he appears in other chapters as well: Concerning the Well of the Oath (Palaea I,

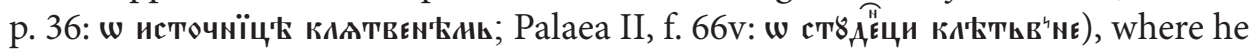
tells Abraham to obey Sarah, who had asked her husband to beget offspring with the slave Hagar ${ }^{39}$; Concerning Circumcision (Palaea I, p. 37: О шь $\rho$ 'замї̈; Palaea II, f. 66v continuation of the chapter Concerning the Well of the Oath), where he performs the ritual and blesses the house of Abraham ${ }^{40}$; in Concerning Lot (Palaea I, p. 39: w AOT'E; Palaea II, f. 68: $w$ A0T'E), which refers to the story of enslavement by Chedorlaomer, rather closely corresponding with the episode in Gen 14,17-20 $0^{41}$. This shows that, as far as the story of Melchizedek in both translations of the Palaea is concerned, the crucial difference is the segmentation of the text ${ }^{42}$. What is more, in the second translation, the commentary on Christ (whom Melchizedek is believed to prefigure) is incorporated into the chapter Concerning Melchizedek (excluding the subtitle Concerning Christ from the first translation), but two passages

\footnotetext{
${ }^{38}$ More on the specific character of the phenomenon, cf. А. ДимитровА, Авторов и преводачески стил в старобългарската агиография, СЛ 45/46, 2012, p. 168 (the entire text on p. 165-171).

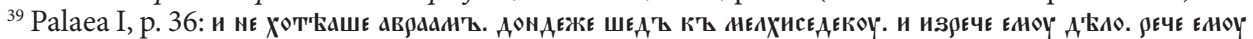

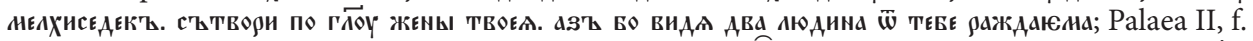

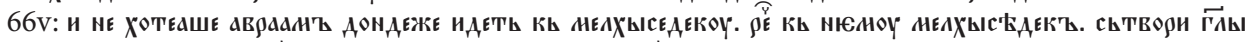

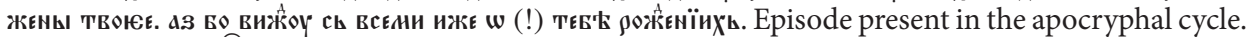

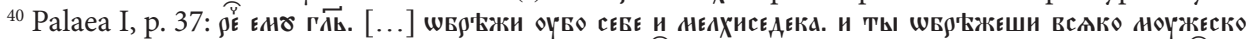

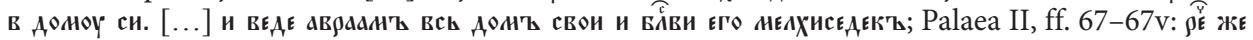

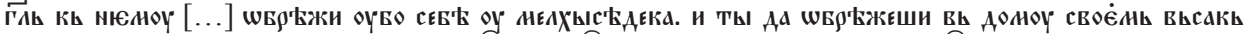

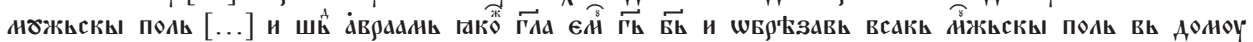

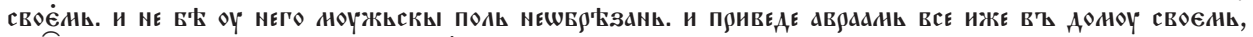

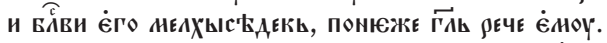

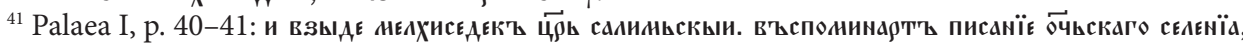

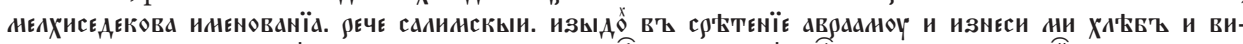

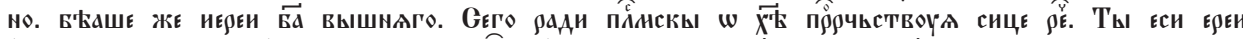

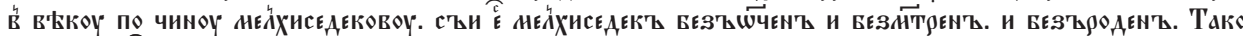

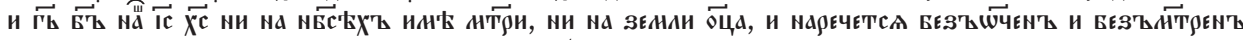

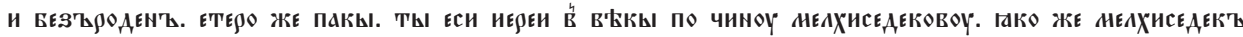

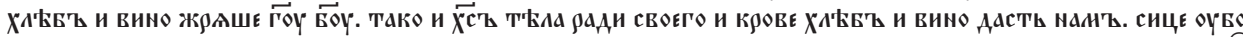

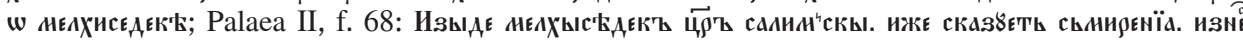

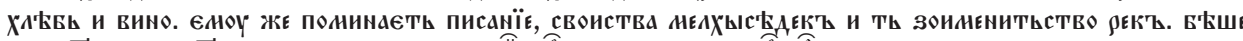

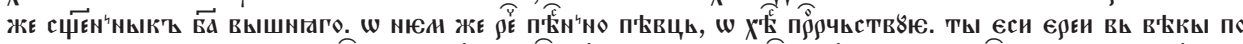

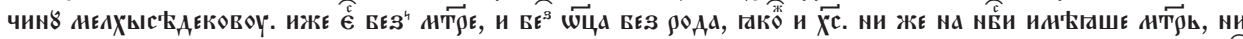

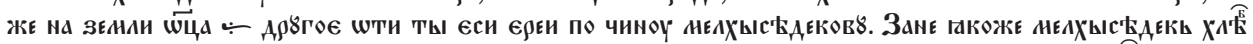

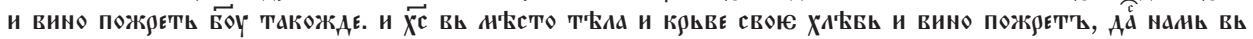

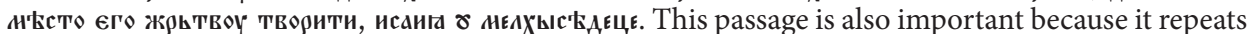
the agnomen of Melchizedek as "without father and mother", and explains it, likening Melchizedek to Christ.

${ }^{42}$ More on the differences in the segmentation of the Palaea text, cf. М.Н. СПЕРАнскиЙ, Югославянские тексты „Исторической палеи” и русские ее тексты, [in:] IDEм, Из истории русско-славянских литературных связей, Москва 1960, p. 127 (on p. 104-147).
} 
are the same in terms of content ${ }^{43}$. Lexical and stylistic differences between the two translations do not indicate any significant differences in their Greek originals; it can even be concluded that the story of Melchizedek contained in each is in fact the same text, and includes the following events: a brief presentation of Melchizedek's family connections and him being sent by his father to obtain oxen for the sacrifice; Melchizedek reflecting on the true Creator of heaven and earth; his objection to the sacrifice to the gods and the threat of being sacrificed by his father; meeting with his brother and escaping the Mount of Olives; his fulfilled plea for the destruction of the heathens and their city; finally, departure for Mount Tabor, his forty year stay there and his meeting with Abraham. These events are described in a consistent chronological and causal order, and a careful reader may observe the process of shaping the character and personality of Melchizedek.

In the story of the King of Salem, it is particularly important to emphasize a fact pointed out by R. Zarzeczny: namely, that all sources consistently have Abraham and Melchizedek believe in the one God, based on their contemplation of the world ${ }^{44}$. It should be noted, however, that there are far more structural similarities shared between the fate of Melchizedek and Abraham recorded in the apocryphal cycle (in both editions) - and to a lesser extent in Palaea Historica. Undoubtedly, some of them already existed in accounts (and texts) preceding the cycle and the Palaea. These similarities are manifested in the following episodes:

1. Origin. Fathers of both characters are pagans who "believe in idols" 45 . Information about the "idolatry" of Melchizedek's father corresponds to the notion

\footnotetext{
${ }^{43}$ This is the conclusion of the story of Melchizedek (after finding that Abraham collected a tithe in

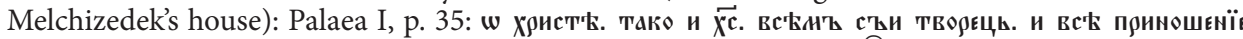

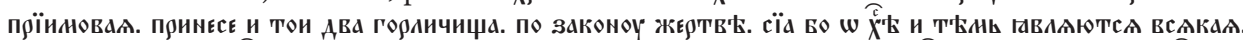

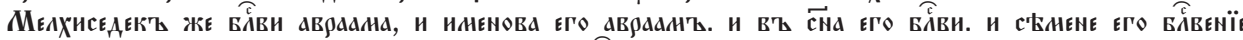

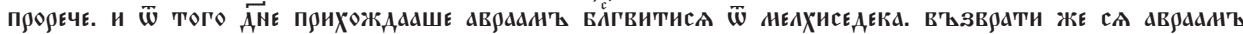

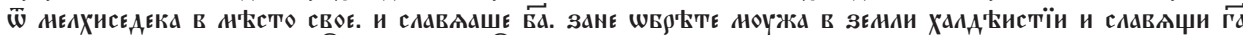

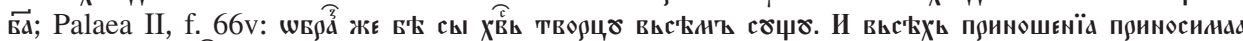
приємающљ. тако

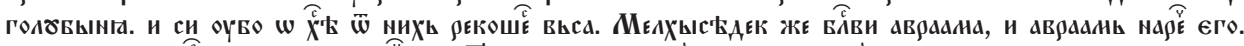

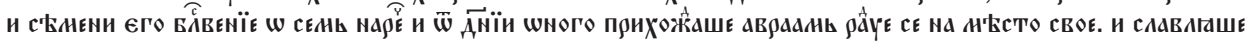

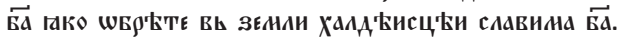

${ }^{44}$ R. ZARZECZnY, op. cit., p. 340.

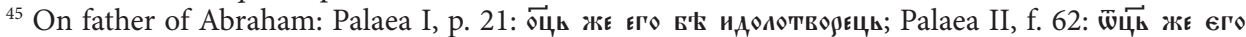

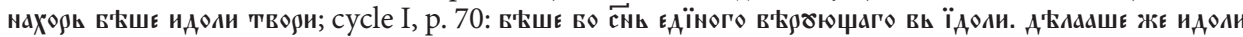

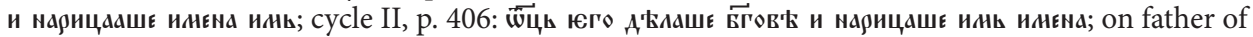

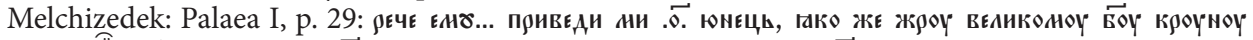

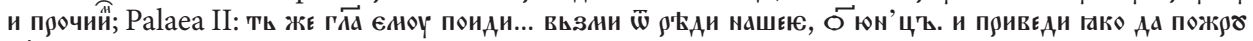

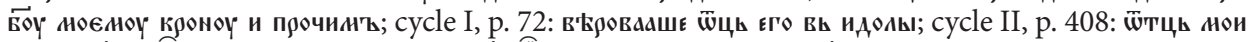

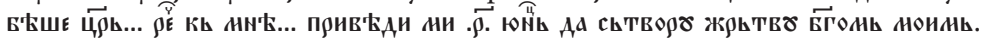


found in Sermon by Athanasius of Alexandria, according to which he was supposedly a "Hellene", i.e. a heathen ${ }^{46}$.

2. Revelation. Abraham and Melchizedek experience a revelation concerning the one God the Creator, expressed in the characteristic reflection - confession. It is worth noting that in both cases, this event takes place at night, in poetically presented circumstances ${ }^{47}$. The lyricism of the scene in the first translation of the Palaea has been pointed out by T. Jovanović ${ }^{48}$. Both characters gain a new awareness as adolescents, but on the threshold of adult life - and it determines all of their subsequent actions.

3. Both Abraham and Melchizedek attempt to persuade their fathers that the latter are wrong to keep their faith, and that the true God whom they should worship is the "creator of heaven and earth" ${ }^{49}$. Opposing his father's beliefs and/or ridiculing the driving force attributed to the idols, Abraham destroys them (by

${ }_{46}[\ldots]$ бяме же отещь ею Елинб же не спасенб, жертву принося идоломъ, cited after: Слово Абанасия архиепископа александрьскаго о Мелхеседеце, [in:] А.Н. Пыпин, ор. сіt., p. 22.

47 On Melchizedek: Palaea I, p. 29-30: в.

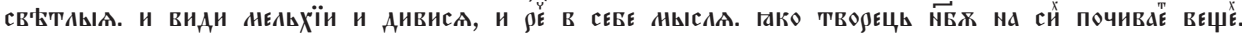

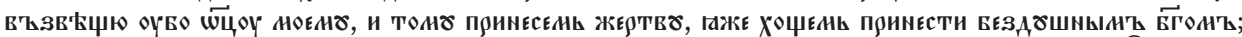

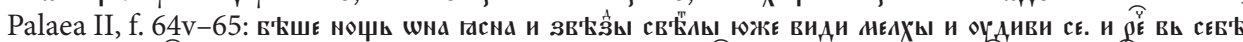

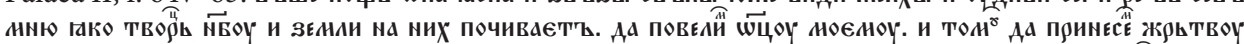

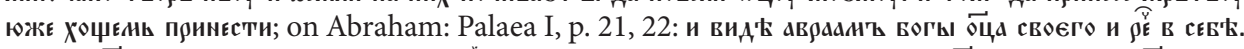

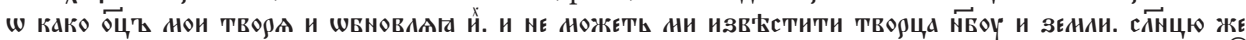

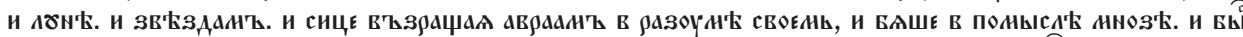

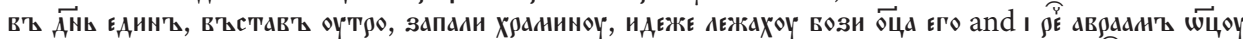

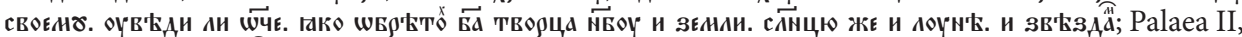

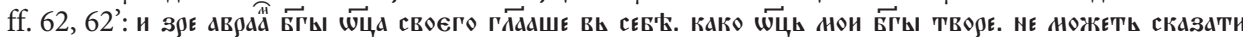

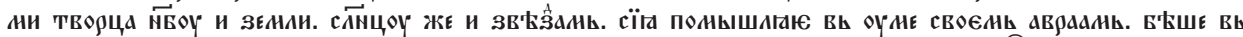

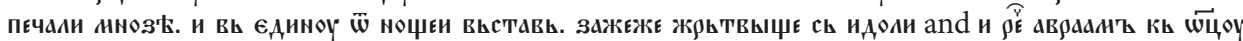

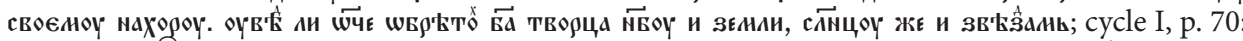

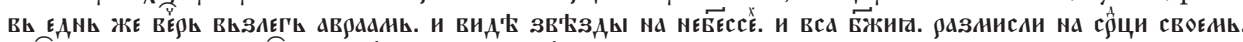

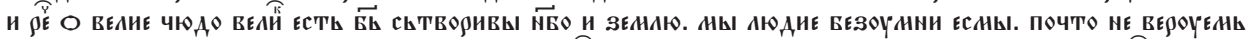

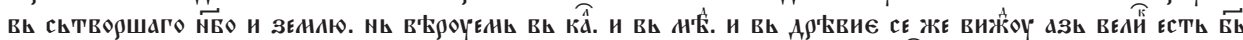

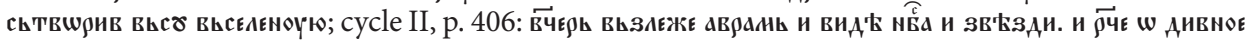

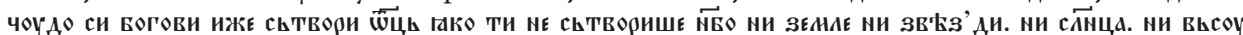

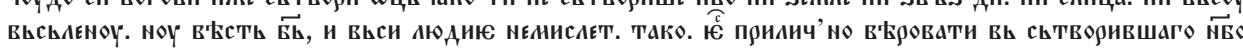

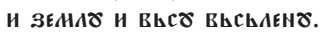

${ }^{48}$ The lyricism of the scene in the first translation of the Palaea was noted by T. Jovanović: Jедно од најлирскијих места у читавом апокрифу, а тиче се Мелхиседековог доживљаја ноћи у којој је гледао звездано небо и дивио се тепоти Створителевих творевина. [...] Ово ретко поетско виђене природе, а нарочито ноћи, има своју варијативност у другим преписима, али нигде не достиже тако успело решене какво се среће у два споменута преписа управо због ретког придева прелун, cited after: Т. ЈовАновић, ор. сіt., p. 227-228.

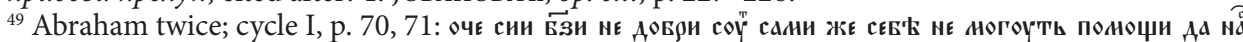

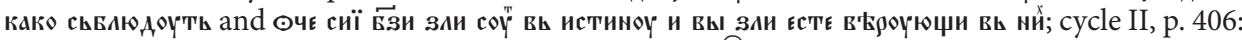

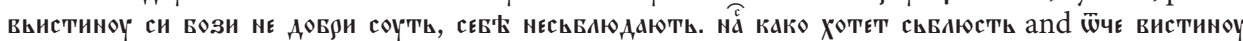

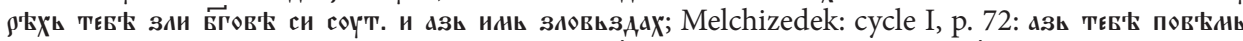

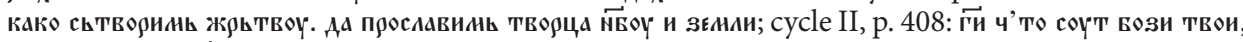

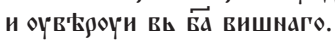


burning, crushing, or throwing them in mud), while Melchizedek refuses to carry out his father's command to bring oxen for the sacrifice ${ }^{50}$.

4. As a result of objecting to his parents, Melchi is sentenced to death as a sacrifice to the deity Cronus, while Abraham's father raises his hand against him - after which both men face the tribulation of spiritual and physical journey: Abraham to the land of Canaan ${ }^{51}$, Melchizedek escaping from his hometown to the Mount of Olives, then to Mount Tabor ${ }^{52}$. It should be emphasized that the story of Abraham in the Palaea is different, as Nahor seems to understand his son's conviction to abandon polytheism, and even expresses disappointment in his own faith ${ }^{53}$.

5. Melchizedek, like Abraham, has his greatness foretold: according to Gen 22,17 , Abraham's offspring will be as numerous "as the stars of heaven and as the

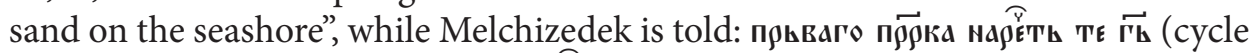

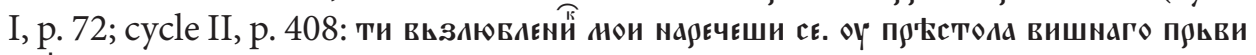

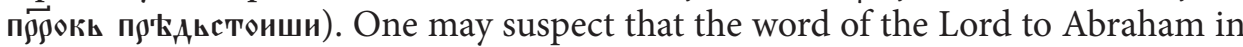
Gen 15,5 (look at the sky and count the stars, if thou be able to number them so shall your offspring), shortly after meeting with Melchizedek and after the defeat of Chedorlaomer, were used in the "pseudo-canonical" nocturnal reflection on the nature of the Creator ${ }^{54}$. Both, moreover, in the Palaea and in the cycle, God is repeatedly referred to as "the Creator of heaven and earth, sun, moon and stars".

6. Both characters are witness - although in different circumstances - to a theophany or angelophany. Melchizedek hears "a voice speaking from heaven", promising him a future as a prophet ${ }^{55}$. According to the Palaea, God tells Abraham

\footnotetext{
${ }^{50}$ Presentation of the family home of the two protagonists as pagan and independent life from the moment of entrustment to the one God fits into the concept of "the evil" and "the good" (sacred and profane) in some interpretations of Vita as a genre, cf. L. Suchaneк, Модель жанра и его индивидуальная реализаиия на примере агиографии, [in:] Gattungen und Genologie der slavischorthodoxen Literaturen des Mittelalters (Dritte Berliner Fachtagung 1988), ed. K.-D. SEemann, Wiesbaden 1988 , p. $259-267$.

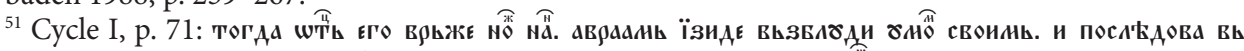

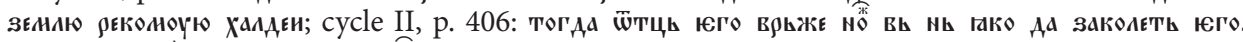

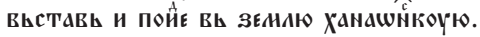

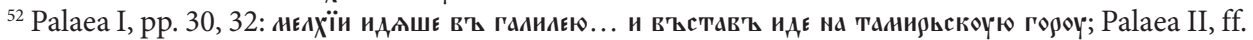

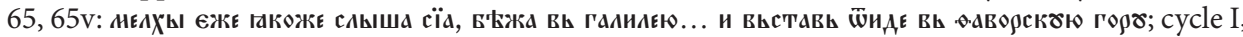

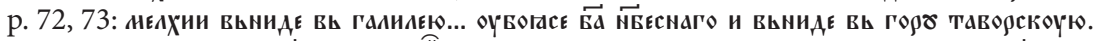

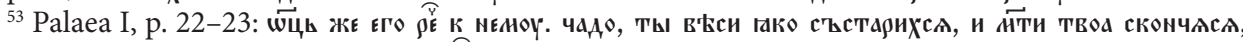

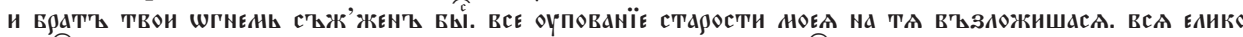

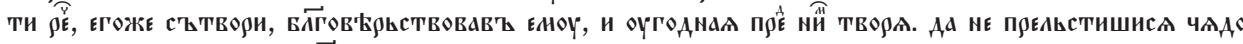

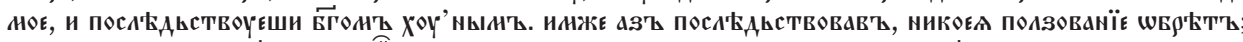

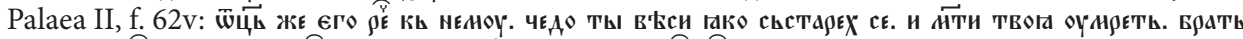

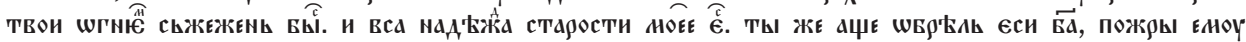

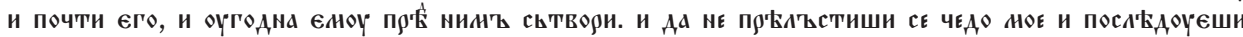

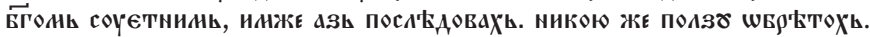

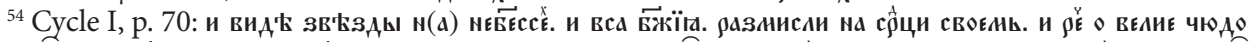

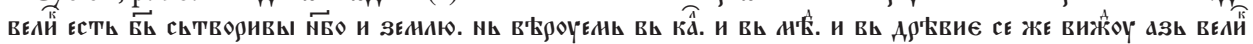

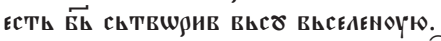

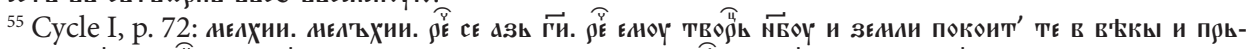

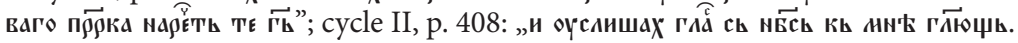


to leave his father and his native land ${ }^{56}$; according to the cycle, Abraham talks to archangel Uriel accompanying him to the "land of the Chaldeans" 57 .

Abraham is sent by the Lord to find Melchizedek on Mount Tabor. Importantly, it is a condition for receiving a blessing ${ }^{58}$. This moment is repeated retrospectively in the chapter Concerning Melchizedek ${ }^{59}$.

7. At some point in their lives, both men are confronted with the horror of human sacrifice: the old king of Salem intends to sacrifice one of his sons (and many children of his nobles) to a deity on whose support he is counting in the planned battle $^{60}$; Abraham is tested by God the Creator ${ }^{61}$. In both cases, however, there is ultimately no sacrifice: at Melchizdek's request, the city of Salim is destroyed (before the slaughter of children), which is preceded by a prayer, which is also a confession

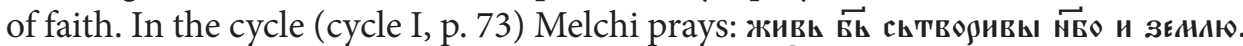

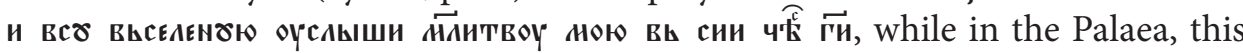

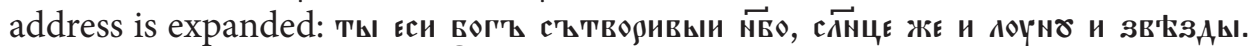

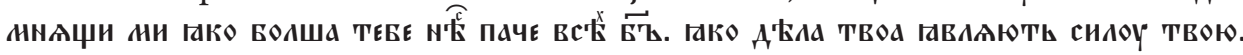

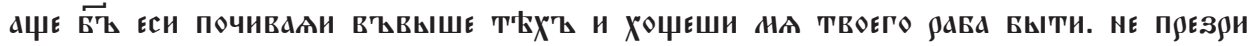
п९ошєнїв нов... (Palaea I, p. 32), and still these words are only an introduction to the plea for the destruction of the sinful city of Salim.

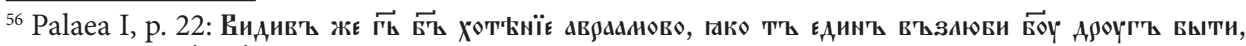

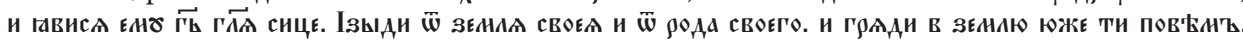

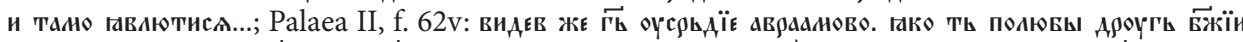

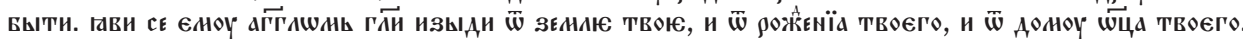

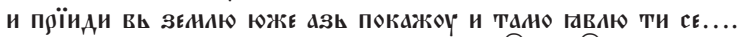

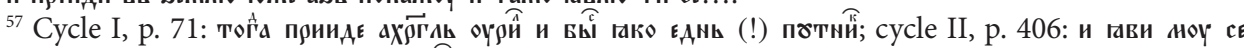

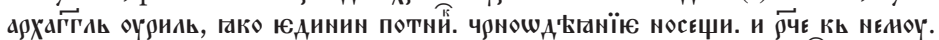

${ }^{58}$ The final episode of the chapter On Abraham: Palaea I, p. 28:

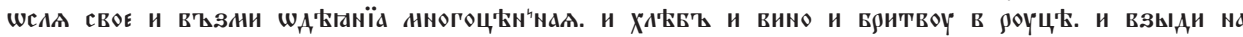

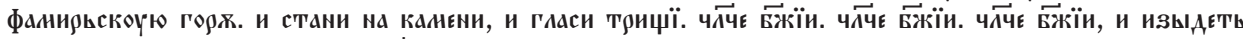

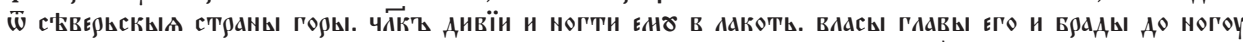

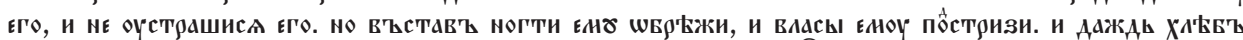

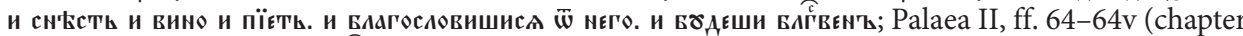

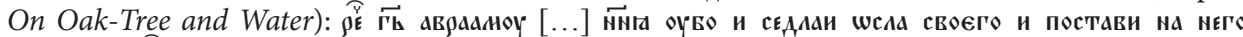

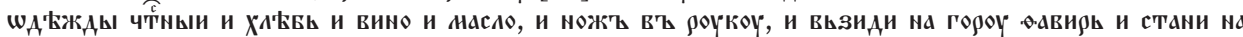
КАНЕны. И вьзови т९їџь

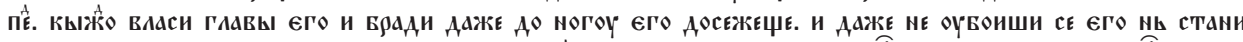

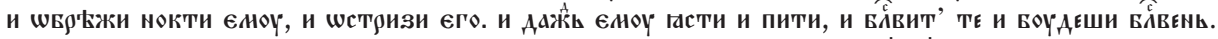

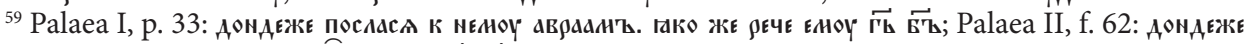

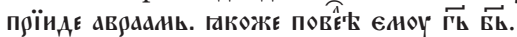

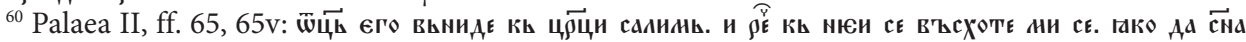

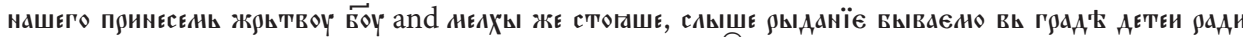

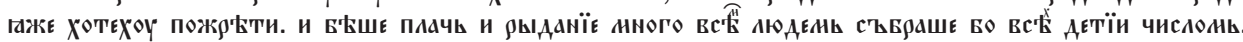

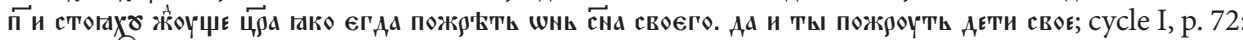

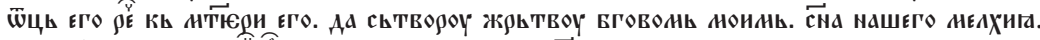

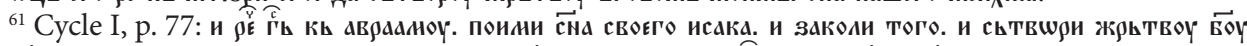

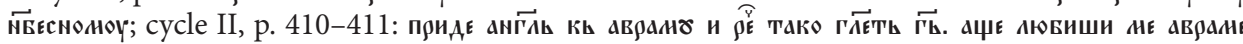

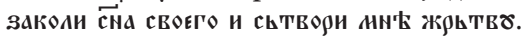


The sacrifice of Isaac is changed to an animal sacrifice at the critical moment ${ }^{62}$.

8. The meeting of the two characters after Melchizedek's forty years' seclusion is a culmination of sorts and a turning point in the fate of the two heroes, which gives them a new sense of dignity: their mutual blessing binds them together. One can see it as a kind of interdependence and shared responsibility, as both are acting as decurions for their goods; they take care of each other: Abraham, upon God's command, finds the hermit Melchizedek, and the latter blesses the two sons of the patriarch at the right time. This may be an echo of the Hebrew tradition preaching that Melchizedek is an ancestor of Abraham, and as such, he is therefore higher in the ancestral hierarchy; announcing the birth of the descendants of Abraham, he also performs a triple function: that of a king, priest, and prophet ${ }^{63}$.

9. Changing the names of the characters entails a change in their social condition and their relationship with the Creator (after they are given "tasks" to complete). The king and the priest initially is known (in the Palaea) under the name 'Melchi', only to be renamed 'Melchizedek' ${ }^{64}$. without any comment, in the final stage of the story, after his meeting with Abraham. The text of the Palaea gives two interpretations of the change of Abraham's name. The first one seems to correspond to the biblical account ${ }^{65}$, according to the second it is Melchizedek who gives Abraham his new name ${ }^{66}$.

The fragments of texts presented above show a number of similarities in the structure of both characters and simultaneously prove the linguistic and stylistic multiplicity of ways in which the same message is expressed. The figure of Abraham was probably created and sanctioned by (literary) tradition earlier than that of Melchizedek; in any event, extra-biblical texts dedicated to him are to a greater

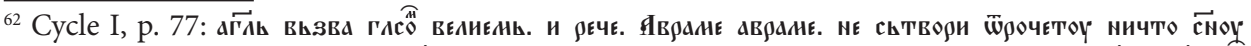

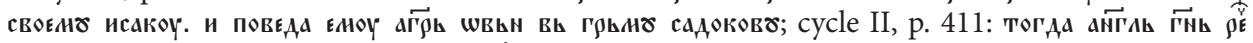

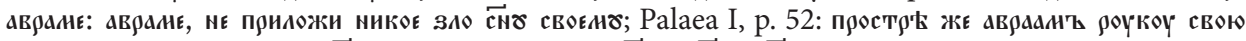

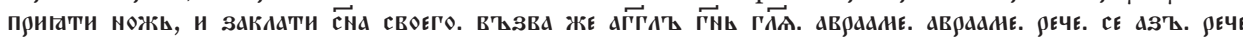

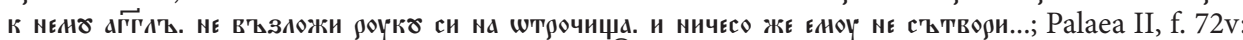

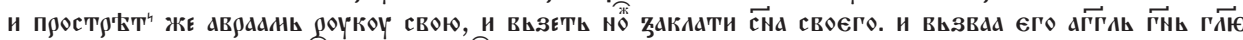

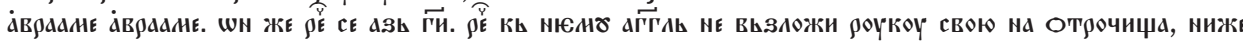
что сьтвори єноу.

${ }^{63}$ Cf. R. ZarZeCZnY, op. cit., p. 333.

${ }^{64}$ Similarly, the first name of Abraham is 'Abram', and Sarah - 'Sarai', cf. Gen 14-17; Gen 17,5. The Hebrew tradition seems to attribute less importance to the change of names: 'Abram' and 'Abraham' are variations on the royal title Abamrama / Abiramu found on cuneiform tablets from the nineteenthseventeenth century BC; 'Sarai' is an older form of the name Sarah, both forms are derived from a Semitic word meaning queen / princess, cf. R. Graves, R. PAtai, op. cit., p. 172.

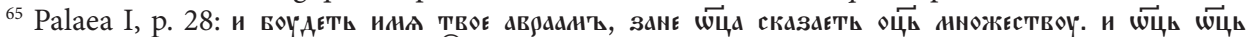

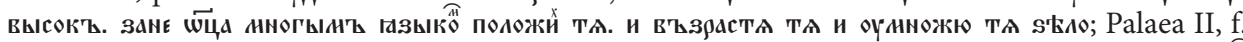

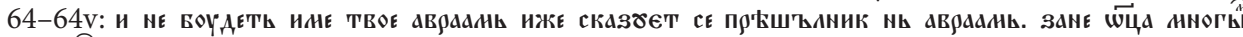
єзыкшิ поставлю те. Cf. Gen 17,5: Neither shall your name any more be called Abram, but your name shall be Abraham; for a father of many nations have I made you [King James Bible 2000].

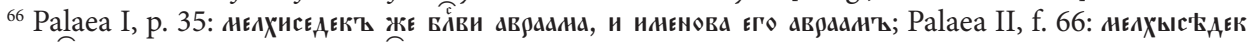

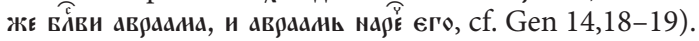


extent based on the themes and motifs of the Old Testament than is the case with Melchizedek. In the opinion of R. Zarzeczny, the image of Melchizedek is based on themes attributed to Abraham according to the Jewish tradition, and the text can be a Christian reworking of the apocryphal story of the conversion of the pa$\operatorname{triarch}^{67}$. This is confirmed in the Slavonic material. Pierluigi Piovanelli draws attention to an important change introduced by the author of Palaea Historica in the biblical account of Athanasius of Alexandria, according to which Melchizedek [...], king of Salem brought out bread and wine (Gen 14,18), which is to supposed to anticipate both the bloodless sacrifice and the role of Melchizedek as a prototype of a Christian priest ${ }^{68}$. It should be noted, however, that Abraham bringing gifts for Melchizedek to Mount Tabor during their first meeting (which makes Abraham an "active" character, one of primary importance in this the episode) is essentially a modification of the episode taking place (in Gen) after the battle with Chedorlaomer and, additionally, moves it in time! At the same time the chapter Concerning Lot replicates the details of the meeting of the holy men from Genesis. These two passages indicate a reciprocity of the two heroes, regarding Abraham and Melchizedek as equals in their functions as patriarchs.

In addition, the beginning of the chapter Concerning Melchizedek (from the Palaea) is surprising. In the first sentence, he is called "one having no parents" 69 , and in the second one none other but his mother and father are mentioned by name, along with their participation in the life of their already adult son. This inconsistency does not seem to bother the author of the Palaea (the Slavonic translator follows the original to the letter), nor does it prompt him to comment on other variants of the story of the king-priest, where his "having no parents" would be explained. What is more, it may have been the result of compiling various textual traditions.

In the "independent" narratives of the Abraham cycle which have their own titles, Melchizedek is the eponymous character only in the first edition (he also appears in the episodes on the announcement of the birth of, as well as the one blessing first Isaac, in Sermon on the Trinity (Отранолювїв аүранав. слово стин троїцв) and then Ishmael, in Sermon on How Sarah Instructed Her Husband Abraham (Слово како сарьра оүчй аврадна); he is also presented in the same situations in the Palaea). The focus - emphasised in the title - of each part of the cycle (as well as chapters of the Palaea) on the chosen hero makes it possible to look at him closely, slow down the pace of the narrative, and make use of such detail (often absent in the Scripture).

${ }^{67}$ Cf. R. ZARZECZNY, op. cit., p. 353.

${ }^{68}$ P. Piovanelli, op. cit., p. 68 . More on changes in the Palaea described as secondary to the text by Athanasius, cf. ibidem, p. 67-68.

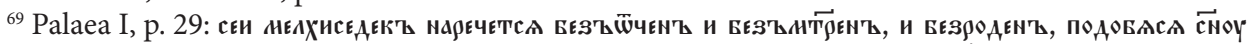

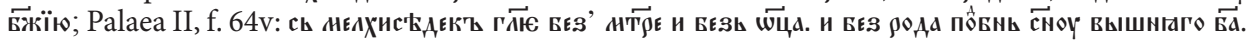


In the second edition of the cycle, the story of Melchizedek is part of the text

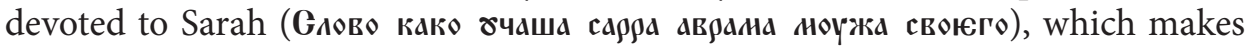
him a hero of seemingly secondary importance, especially since the text opens with Sarah's statement about the necessity of Abraham having offspring by the slave Hagar, Abraham's objection is a direct cause of confrontation with the authority of Melchizedek, and the last sentence of the text refers to Abraham's obedience to the advice of his wife and Melchizedek as well as the birth of Ishmael. Nevertheless, the way in which information regarding Melchizedek is presented is rather noteworthy. Instructed by an angel, Abraham goes to Mount Tabor, where he fulfills the orders received (bringing Melchizedek bread and wine, cutting his hair and nails). It is only at that point that we learn, from Melchizedek himself, his story, told to Abraham using direct speech (here and below cited after: cycle II,

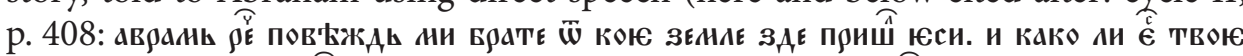

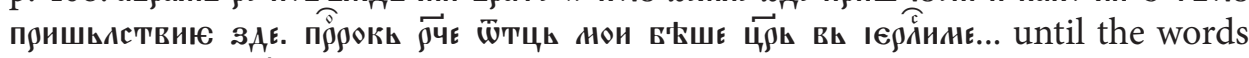

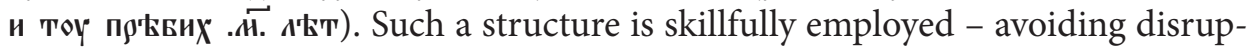
tion of the narrative of Sarah and Abraham with digression about a character yet to appear, therefore not disturbing the chronology of events - when it is difficult, given the lack of an independent section devoted to the character, to present these two themes that are almost parallel. The use of such a procedure is interesting for yet another reason ${ }^{70}$ : the literary Melchizedek creates his own "autobiography", so the author of edition II of the cycle places the story within the story (Melchizedek's "autobiography" within the narrative of Abraham going to Mount Tabor) ${ }^{71}$. In his autobiographical account, the prophet describes in detail the events of his youth: the necessity to offer a sacrifice to pagan gods, the voice from the sky which caused his conversion, the feud with his father about their respective faiths, the prospect of being sacrificed, intervention by his mother, who sends another son to

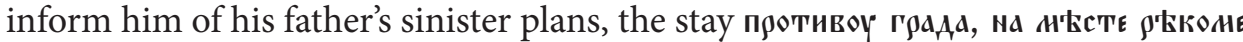
маслина, the destruction of his father and the city, finally leaving for Mount Tabor and his forty year stay there. The only jarring element in Melchizedek account is

\footnotetext{
${ }^{70}$ Especially in the context of the low frequency of the autobiographical genre in the Old Testament: От този жанр в старозаветните текстове има само следи. [...] Те показват, че жанргт все пак е познат. В древната египетска титература е известна творбата „Повест на Синухе/m/", в която под форма на автобиография на египетски сановник се разказва за живота в Ретену (египетското название за Южен Ханаан). Не би могло да има съмнение, че подобни творби са били известни сред образованите крвгове в Израил, а чрез тях творбите поне отчасти са давали отзвук и като модел за подражание в по-иирок обществен крбг. [...] В една автобиограбия и в автобиографични бележки може да се очаква личните спомени да са били пречупени през призмата на автобиограба съобразно онова, което го е вблнувало и кбм което се е стремял в живота и в служението си. затова някои събития и характеристики на лица могат да бъдат описани бегло, други - пьлнокрбвно, а трети изобщо да са изпуснати, понеже са били сметнати за маловажни. [...] Примери. 1) Йер. 1:1-10 - призоваването на пророка, с някои автобиограбични данни. 2) Йез. 1:1-3 - призоваването на пророка. 3) Ам. 7:10-17 - за разногласието с пьрвосвещеника във Ветил, cited after: Н. ШивАРов, Херменевтика на Стария завет, София 2009, p. 70-71.

${ }^{71}$ On the inadequacy of the figure of "hagiographer-hero", cf. e.g.: В. Грудков, Житие на българския Антихрист, София 2010, p. 19-20.
} 


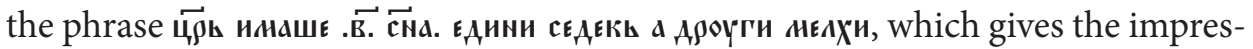
sion that the author of cycle II inserted it mechanically from some narrative of Melchizedek in the third person singular.

It is also worthwhile to look at the history of Melchizedek - in the Palaea and the cycle - as a possible "prototype" or a particular variant of a vita. The text of the Prologue for 22 May focuses on two closely related events in the life of the hero: his realization of the true God the Creator when he is sent by his father for oxen to be sacrificed to pagan gods and after his escape to Mount Tabor, meeting with Abraham and blessing him ${ }^{72}$. Both of these events are found in the cycle and the Palaea, which, given their focus on the content of the biblical narrative, can be considered to be description of the lives (vitae) of holy men and thus "hagiographic": they emphasize the function of Melchizedek as an intransigent "priest of God Most High", and that every single one of Abraham's actions - leaving his father, travelling with his family to new places of residence, meeting unusual travelers under the oak of Mamre, sacrificing his son, covenant with God, even punishing the sinner Lot - is motivated by his obedience to God's will or his attempts to ascertain God's will. This in turn can be considered as a quality of the "man of God", idealized for the purpose of the text showing the right way of conduct (and therefore a vita) ${ }^{73}$. If, in the so-called apocryphal vitae, the rhetoric and panegyrical elements are minimised; the narrative beginning dominates (the whole narrative being in the third person singular); the story is constructed on the basis of the accumulation of events and dialogues; there are many characters and details; and the vitae are short texts presenting a certain problem, event, or idea ${ }^{74}$; then the stories of Melchizedek and Abraham from the cycle and the Palaea meet these characteristics of the genre! Narratives in the Palaea and the cycle provide excellent material for the hagiography of both characters (both indeed have liturgical memorials and Prologue vitae texts separate from other Forefathers), especially if we assume that genre boundaries should not be viewed as immutable, but quite to the contrary as historically mobile and changeable ${ }^{75}$. All chapters of the Palaea in which Melchizedek appears

\footnotetext{
${ }^{72}$ The text of the prologue begins with quoting the genealogy of Melchizedek as a descendant of Ham, the son of the "king of the land of Palestine" Melchil and ends with giving the age of the prophet-priest at the time of his death (128 years), cf.: В той же день память в святых отияа нашего Мелхиседека (из Румянщевскаго пролога XV-XVI в., № 521), [in:] А.Н. Пыпин, ор. сіt., p. 21.

73 К. Иванова, Житията в старата българска титература, [in:] Стара българска титература, vol. IV. Житиеписни творби, coll. et ed. К. Иванова, София 1986, p. 8-9.

${ }^{74}$ Д. ПеткАновА, Апокрифната литература в България, [in:] Стара българска литература, vol. I. Апокрифи, coll. et ed. Д. ПЕТКАНОвА, София 1982, p. 14.

${ }^{75}$ В. ИзмИРлИЕвА, Една гледна точка към понятието „жанр” в старобългаристиката, СЛ 25/26, 1991, p. 35 (the entire text on p. 29-37). Valentina Izmirlieva joins the quoted discussion on the text and genre; she proposes to consider the genre as a set of characteristics within the text. Noteworthy is the concept according to which the agent supposedly binding the genre and the functional implementation of the text was its potential for inclusion in certain communication situations. For more on this subject see also two volumes of materials devoted to the problem of
} 
contain material depicting the hero's entire life. The only time of Melchizedek's life not included in the Palaea and the cycle is his death - which is also an important component of the vita ${ }^{76}$.

A similar case is known, moreover, in medieval literature (Byzantine, and therefore Slavonic). The so-called Lives of the Prophets, the Greek codification of which is attributed to Epiphanius of Cyprus, are probably based on Hebrew legends and were incorporated into the biblical canon as introductions to the Old Testament books of the prophets. Brief commentaries about the prophets containing a bio- or hagiographic element were treated as vitae. This was the case, for example, with the life (vita) of prophet Jeremiah, whose Old Bulgarian translation was included in books for liturgical use (patericons, prologues, and Menaion of Metropolitan Macarius) $)^{77}$. The story of Melchizedek included in the Prologue is not, of course, the same text as the one in the Palaea or the cycle, but has (extrabiblical) elements in common with them. Such sanctioning of extra-biblical material is moreover a relatively commonplace procedure (one could mention the reading of the so-called Apocrypha on the days of the liturgical memorials ${ }^{78}$ ). We can therefore probably assume that the narratives of Abraham and Melchizedek could have been treated as elements of their hagiography or even "para-vitae". The stories of Melchizedek and Abraham are different, representing different types of heroes: in the light of traditionally regarded types of holiness Abraham would be the father of the nation, a "holy man", while Melchizedek a "priest" commanding full authority, and the edition of the "original text" indicated above, in the chapter about Melchizedek further changes balance in favor of Abraham. However, the "points of contact" and "turning points" in their fates provide grounds to see the two characters almost as adventure heroes ${ }^{79}$. Certain qualities can be noticed in

the theory of medieval genres cited earlier and discussed by V. Izmirlieva: Gattungsprobleme der älteren slavischen Literaturen (Berliner Fachtagung 1981). Im Auftrag der Berliner Forschungsgruppe „Ältere slavische Literaturen, ed. K.-D. SEemanN, Berlin 1984, where in particular: K.-D. SEemanN, Thesen zum mittelalterlichen Literaturtypus und zur Gattungssystematik am Beispiel der altrussischen Literatur, p. 277-290 and Gattung und Narration in den älteren slavischen Literaturen (Zweite Berliner Fachtagung 1984). Im Auftrag der Berliner Forschungsgruppe „Ältere slavische Literaturen, ed. IDEM, Wiesbaden 1987, where in particular: N.W. Ingham, Narrative Mode and Literary Kind in Old Russian: Some Theses, p. 173-184.

${ }^{76} \mathrm{Cf}$. L. SuchaneK, op. cit. His death is recorded in the prologue vita.

${ }_{77}$ Cf. Г. Минчев, Пророк Иеремия и змиите. Книжовни измерения на фолклорната обредност, [in:] От Честния пояс на Богородица до коланчето за рожба. Изследвания по изкуствознание и културна антропология в чест на проф. Елка Бакалова, еd. М. САНтовА, Б. ПенковА, И. СТАНОЕВА, М. ИваНОВА, СофИЯ 2010, p. 100-113.

${ }^{78}$ On using non-canon texts in the liturgy cf. G. Minczew, Starotestamentowe teksty pseudokanoniczne w południowosłowiańskiej tradycji rękopiśmiennej, [in:] Apokryfy i legendy starotestamentowe Słowian południowych, sel. et ed. G. Minczew, M. SkowroneK, Kraków 2006, p. XIX-XX (the entire text on p. XVII-XLIII).

${ }^{79}$ More about the properties of narrative genres in Old Bulgarian literature (based on Alexander romance, Barlaam and Joasaph, Stephanite and Ichnilat, Tales of Solomon and Kitovras, Tale of princess Persika and selected narratives on miracles) see in: М. ЙоновА, Жанрови проблеми и особености на старобългарската белетристика, СЛ 19, 1986, р. 90-100. 
the way the characters are presented: reminiscent not so much of martyria (as a prefiguration of vitae), but of episodes and anecdotes that constitute the material for ancient biographies ${ }^{80}$.

Also noteworthy is the organization of content in these two texts: the Palaea and the apocryphal cycle. Both disrupt the chronology of the Bible (in the Palaea, the section Concerning Lot which describes the enslavement of Lot by Chedorlaomer, as a result of which Abraham meets Melchizedek, was included in the chapters Concerning Abraham and Concerning Melchizedek), both are also divided into smaller fragments associated with specific characters, with separate titles, which - apart from improving the orientation within the text - serves as a method of systematization of events concerning individual characters ${ }^{81}$.

The approach to time is an important and interesting element of the structure of the texts. The chapter Concerning Melchizedek (from the Palaea) consistently maintains the chronology of events, operating the scene or retardation at the same time. For example, Queen Salima orders her elder son to inform the younger one of impending danger. In the next sentence, Melchizedek responds to the information he has heard; the author of the text skips Sedek's journey and his conversation with his brother - since apparently neither contributes to the sequence of events - immediately describing the results. A similar "jump" can be observed in the later fate of Melchizedek: one sentence states that he went to Mount Tabor for forty years, and - evidently after these forty years of hermit life - he met with Abraham who

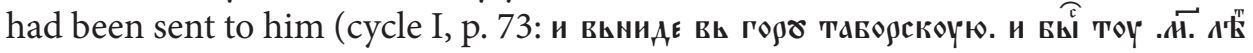
мє пюоговори ки чйкоү). It should be noted that in the chapter Concerning Melchizedek dialogue is an important element, as it both advances the plot and makes the narrative interesting. Thus, contained here are some key dialogues: Melchi with his father, Queen Salima with her eldest son, and finally Melchizedek with Abraham. Aside from dialogues also present in the Palaea are vivid depictions of events (for example the last meeting of the king's sons before the destruction of the city).

The lack of chronological order in edition I of the cycle (for example, Homily on the Trinity, announcing the birth of Isaac, comes after Homily On Sarah and Homily on Isaac, where that very Isaac is born, and even lives as an adult) suggests that the stories functioned independently of each other, since keeping chronology is not a priority. In this case, the repetition of content in different texts of the cycle

\footnotetext{
${ }^{80}$ Cf. e.g.: J. Niemirska-Pliszczyńska, Swetoniusz i jego dzieło, [in:] Gajusz Swetoniusz Trankwillus, Żywoty cezarów, vol. I, trans. et ed. J. Niemirska-Pliszczyńska, praefatio J. WolSKI, Wrocław 2004, p. XIII-XVII (chapter Biografia jako gatunek literacki); М.Л. ГАСПАРОВ, Светоний и его Книга, [in:] ГАЙ СВЕТОНИЙ ТРАНКВИЛЛ, Жизнь двенадиати изезарей, еd. М.Л. ГАСПАРОв, Е.М. ШтаЕРман, Москва 1964, p. 269, 275; also: A. SAlsKa, Biografia, [in:] Słownik rodzajów i gatunków literackich, ed. G. GazdA, S. TyniecKa-MaKowsKa, Kraków 2006, p. 90-91.

${ }^{81}$ Similar headlines (titles) are found in manuscript copies of the Bible from a later period, v. remarks on the so-called Bible of Pšina in: Г. Минчев, Пшинская Библия первой половины XVI в. - малоизвестная южнославянская рукопись, содержащая перевод Восьмикнижия, [in:] Священное писание как фактор языкового и титературного развития..., р. 223-240.
} 
would constitute the "context" for other events being referred to in the narrative for the first time: part of the cycle, rather than the more extensive chapters of the Palaea which are arranged in a tale of adventure clearly indicating a model of conduct or moral teaching ${ }^{82}$. All this seems to confirm the validity of the theory proclaiming that the cycle was independent from the Palaea, emphasizing the alleged use of the former as one of the sources for the latter ${ }^{83}$.

The biblical elements are present in varying degrees in the cycle and the $\mathrm{Pa}$ laea: the story of the youth of Melchizedek, details of his meeting with Abraham on Mount Tabor, and his commitment to the family life of the patriarch, are an accompaniment and commentary, and not a distortion of the official account, while at the same time they facilite its perception ${ }^{84}$. After all, according to P. Piovanelli, The Story of Melchizedek (which highlights Melchizedek's priesthood and his offering gifts as the most important element) by Athanasius was used - after appropriate alterations, including Abraham as the one making the offering - as the source of the relevant passage in the Palaea ${ }^{85}$. As a result, the Palaea, as regards the story of Melchizedek, contains content of character both "biblical and canonical" (Melchizedek, as the prototype of a priest, making an offering in the Chapter Chedorlaomer / Xолодогонолова) - and "extra-biblical" (as in the cycle: the youth of Melchizedek, instructing Abraham to follow Sarah's advice and sire offspring by Hagar, blessing the sons of Abraham - those present in the Homily of Athanasius were also sanctioned by the liturgy to be read on the liturgical memorial

\footnotetext{
${ }^{82}$ Cf.: Така съчиненията, останали извън канона, притежават за българските книжовници същзото достойнство и значение - като учителната християнска литература, cited after: А. МилтеновА, А. АнгушевА, Апокрифи, [in:] История на българската средновековна титература, еd. А. Милтенова, София 2008, р. 214.

${ }^{83}$ Scholars proclaiming the independent character of the cycle include Michail Speranskij (cf. М.Н. СПЕРАнСКИЙ, Югославянские тексты Исторической палеи и русские ее тексты, [in:] IDEм, Из истории русско-славянских литературных связей, Москва 1960, p. 115-116) and Vladimir Istrin (cf. В.М. ИстРИн, Замечания о составе Толковой палеи, ИОРЯС 2, 1897, p. 189 200) in opposition to the earlier work of E. Turdeanu, who argued that the cycle was used instead of the Palaea (cf. E. Turdeanu, La Palaea...; cf. also: A. Miltenova, The Apocryphal Series about Abraham...; вAdeм, Апокрифи за Авраам, [in:] Старобългарска литература. Енциклопедичен речник, coll. et ed. Д. Петканова, Велико Търново 2003, p. 41).

${ }^{84}$ Cf.: Неофициалният характер на апокрифните тегенди, както и изобщо на апокрифната литература, се отразява върху тяхната поетика и стилистика. Те са значително по-близко до народното мислене и до характера на фолклорното повествование. Често пвти тази близост е вторична, резултат е от битуването на библейската легенда на неофициално ниво, cited after: Кр. СтАнчев, Стилистика и жанрове на старобългарската литература, София 1985, p. 92.

${ }^{85}$ The Story of Melchizedek, written in Greek and attributed to Athanasius, patriarch of Alexandria (ca. 295-373 C.E.), is an extremely popular work from late antiquity that provides a short account of the origins and early life of the otherwise elusive priest-king of Salem prior to his meeting with Abraham (Gen 14,18-20) [...], translated into all of the languages of the Christian Orient (Coptic, Syriac, Arabic, Ethiopic, Armenian, Georgian, Slavonic, and Romanian) and incorporated in a slightly different form into the Greek Palaea Historica, a ninth-century compendium of biblical history from Adam to David which was also translated into Slavonic and Romanian, cited after: P. Piovanelli, op. cit., p. 64.
} 
on 22 May). Such a process, called "(secondary) liturgization" of pseudo-canon themes, affected stories known in numerous variations; the best-known include the story of King Abgar, who wrote a letter to Christ (and received a reply), and the fight of Archangel Michael against Satanael, which is the basis of the feast of Sobor (assemblage) of Archangel Michael and all the Bodiless Powers of Heaven ${ }^{86}$. Therefore, it seems more appropriate to use for both these texts (i.e. the Palaea and the apocryphal cycle) the term "parabiblical literature" ${ }^{87}$, rather than "apocryphal", "non-canonical" or "extracanonical" 88 . Parabiblical literature emphasizes events that seem interesting from the point of view of the story, which can be seen very clearly in the Palaea and the cycle ${ }^{89}$.

Selected works devoted to Melchizedek also confirm that the characteristics of the genre determine the narrative. For example, in the text of the Prologue on 22 May the dominating feature is a "prediction" or a kind of summary ${ }^{90}$, while in the Palaea and the cycle the main narrative mode is an exchange of rejoinders between the characters that adds drama to the story, but embedded within the narrative and interleaved and supplemented with description.

Conclusion. The most important reflection upon reading the story of Melchizedek in Palaea Historica and the so-called apocryphal cycle is that char-

\footnotetext{
${ }^{86}$ On the so-called liturgisation of non-canonical texts, cf. A. NAumow, Apokryfy w systemie literatury cerkiewnosłowiańskiej, Wrocław-Warszawa-Kraków-Gdańsk 1976, p. 64; M. SкowroneK, G. MinCzEw, Cykl o królu Abgarze w bizantyńsko-stowiańskiej tradycji rękopiśmiennej. Wybrane problemy tekstologiczne, KWSS 3, 2001, p. 305-336; Г. Минчев, М. Сковронек, Цикълът за иар Авгар във византийско-славянската рбкописна традиция, [in:] Средновековна християнска Европа. Изток и Запад, ed. В. ГюзЕЛЕв, А. МилТеНовА, София 2002, p. 324-342; G. Minczew, Święta księga - ikona - obrzęd. Teksty kanoniczne i pseudokanoniczne a ich funkcjonowanie w sztuce sakralnej i folklorze prawosławnych Stowian na Bałkanach, Łódź 2003 (chapter Wtórna liturgizacja legendy o św. Sisiniju i diable, p. 124-126); M. SKOWRONEK, Legenda o królu Abgarze w wybranych słowiańskich tekstach użytku liturgicznego, [in:] Biblia Slavorum Apocryphorum. Novum Testamentum, Materialy $z$ Międzynarodowej konferencji naukowej „Biblia Slavorum Apocryphorum. II. Novum Testamentum”, Łódź, 15-17 maja 2009, ed. G. Minczew, M. SkowroneK, I. Petrov, Łódź 2009, p. 131-140.

${ }^{87}$ On the term cf. A. Lange, U. Mittmann-Richert, Annotated List of the Texts from the Judaean Desert Classified by the Content and Genre, DJD 39, 2002, p. 117 (the entire text on p. 115-121).

${ }^{88}$ That special status of "parabiblical" stories which could include the Palaea and parts of the cycle, sanctions an observation that supposedly 'Парабиблейската литература' (извбн библейския корпус) векове наред притежава не по-мальк авторитет от каноничните текстове. Въпреки препорвчителните списъии и решенията на иьрковните събори (които са се превеждали от гръики и са се преписвали за една доста ограничена аудитория), „апокрифната книжнина” в България е изключително популярна, cited after: А. МилтеновА, А. АнгушевА, ор. cit., p. 217.

${ }^{89}$ Ясно е, че сюжетната разработка предполага много по-голям обем на повествованието, сf. К. СТАНЧЕВ, op. cit., p. 86.

${ }^{90}$ In the text of the prologue, there are three instances of the use of direct speech: the profession of faith of Melchizedek: тому было тюпо принести жертву, иже небеса створи и на нихъ почиваеть; his assessment of his father's pagan beliefs: воскую, отче, приносиши жертву болваномъ, люпо ти бы въздати небесному Богу?; a promise given by the pagan king Melchil to his wife to sacrifice one of his sons не мни, яко хошу гнтвом убити его, нъ мещивь сребьи, да аще падеть мне, и заколю своего азб, cited after: В той же день память в святых отиа нашего Мелхиседека..., p. 21.
} 
acters in these texts are more defined than in the Old Testament. This results directly from the structure of these parabiblical works: division into chapters (in the Palaea) or separate parts (in the cycle), focusing on a character or event. Such structure corresponds with a more extensive development of causality (than in the Bible), resulting in an impression that one is following the heroes' "adventures". Additional material concerning individual characters found in chapters or parts of the cycle where they are not mentioned in the title is also noteworthy - complementing the main narrative, though sometimes inconsistent, or even contrary to previously presented content. Such inconsistency may indicate a mosaic nature of parabiblical works, being, after all, essentially based on the Old Testament. Conflict of content could indeed be overlooked, if the cycle or the Palaea were read in fragments, focusing on selected themes; it is noticeable only when the characters' story is seen as a whole, or if one looks to biblical hypertext for references.

Secondly, the conclusions from reading these parabiblical texts (such as $\mathrm{Pa}$ laea Historica and the cycle) provide grounds to seek a prefiguration of vitae (Old Testament). The history of Melchizedek (and Abraham) contained therein reflects the parallel story found in the Bible, while the extra-biblical elements serve as "inspiration"; they attract the attention and interest of the reader/listener, becoming embedded in one's memory. While they retain the essential character of the biblical narrative (a story in the third person singular, with quoted dialogue/direct speech), there are also some departures from it. From a formal point of view, the most interesting phenomenon is the presence - in the second edition of the cycle - of the form of an autobiography (in Melchizedek's monologue), virtually absent in the Old Testament. It is relatively easy to explain why the "parabiblical" Melchizedek is a figure based to a lesser extent on the Old Testament model. The fairly accurate description of the life of Abraham in Genesis opens (in his biography) only a few places that can be filled in with extra- or non-biblical details; in the case of the king-priest, the Palaea and the cycle - using material preserved in early Christian narratives - add information about several decades of life until the first meeting with Abraham (regardless of whether it is moved to the top of Mount Tabor and other circumstances) and several later episodes. What is more, the story of Melchizedek in the Palaea is essentially a complete (from pointing the parents until the age of maturity) biography (vita). In this way, Melchizedek of the Palaea ceases to be a hero "out of nowhere" and is firmly rooted in the Biblical realities genological, topographical, and temporal. On the story of Melchizedek, it is clear that the Palaea serves as a summary, but also a commentary on the Old Testament.

Finally, it is worth returning to the question of utility and functional value of texts ${ }^{91}$. The Palaea - unlike medieval chronicles, which also start with the descen-

\footnotetext{
${ }^{91}$ There is not enough space here to describe in detail the functionality of the text - both the story of Melchizedek (and Abraham), and the Palea as such. Suffice it to mention that regarding the relationship between the function of a medieval literary text in terms of genre there are two opposing views prevailing, see for example В. ИзмирлиевА, op. cit., work cited by her: N. InGHAм, Genre-
} 
dants of Shem, Ham and Japheth, if not creation itself - does not lead the reader up to its time (i.e. the ninth century, when, according to most scholars, it was written). It can be concluded that, as a parabiblical story (subtly "alternative" to the Old Testament due to the extra-biblical material) it completes and orders the official message. The "extrabiblical" Melchizedek becomes a distinctive figure in the history of the chosen people and the history of salvation.

\title{
Translated by Katarzyna Gucio
}

\begin{abstract}
The article analyses the story of the prophet-king Melchizedek (mentioned in Gen 14,1720, Ps 110,4 and three passages in Heb: 5,6-10, 6,20, 7,1-17), recorded in Slavonic historical texts: the first and second translation of Palaea Historica, and the first and second edition of the so-called apocryphal cycle of Abraham (in which there are several references to Melchizedek). Compared to the scarce information about Melchizedek from the Old and New Testament, stories of extra-biblical origin communicate a significant amount of detail concerning the king-priest, comprising a description of nearly all of his life. Comparison of key episodes in the life of Melchizedek and Abraham (such as origin, revelation, conflict with their pagan parent, leaving home and journey, promise of greatness given by God, testimony or theophany or angelophany, experience of human sacrifice, a change of name) in the Palaea and the cycle confirms - based on the Slavonic material - analogies in the construction of the two protagonists. Both accounts - in the Palaea and the cycle - make the characters more "full-blooded" than in the Bible. The story of Melchizedek presented in the Palaea is characterised by fragmentation (being contained in four chapters), and disrupts chronological order to a small degree, emphasising cause-and-effect relationships, while at the same time it can be considered as a prototype or a singular variant of Vitae: the structure and selection of content of the bio- or hagiographic story meet the characteristics of the genre.
\end{abstract}

Keywords: Old-Church-Slavonic literary texts, textology, Palaea Historica.

Małgorzata Skowronek

Katedra Filologii Słowiańskiej

Wydział Filologiczny, Uniwersytet Łódzki

90-236 Łódź, ul. Pomorska 171/173

malgorzata.skowronek@uni.lodz.pl

Theory and Old Russian Literature, SEEJ 31.2, 1987, p. 234-245, and volumes: Gattungsprobleme der älteren slavischen Literaturen... and Gattung und Narration... 